\title{
Faith-Inspired Education in Ghana: A Historical Case Example
}

By Jill Olivier and Quentin Wodon

In order to understand the current role of faith-inspired schools (FISs) in Africa and some of the debates about the magnitude of the services they provide, it is useful to consider their presence in a historical perspective. Faith-inspired schools have a long and distinguished tradition in sub-Saharan Africa. The purpose of this article is to sketch that history using the case of Ghana, a country where FISs date back to early Islamic schools and, as of the $16^{\text {th }}$ century, to Christian missionary activities. ${ }^{1}$

The current status of FISs in Ghana is best understood in the context of the tumultuous historical ebb and flow of engagement. (For an assessment of the current role and scope of FISs in Ghana, see the article by Adoho et al. in this issue.) It is important to understand that the number of FISs, and specifically mission schools, grew significantly in Ghana during the $19^{\text {th }}$ century. By 1950 almost all children enrolled in school attended missionary schools. ${ }^{2}$ Islamic schools had a smaller footprint, but they played an important role in the northern Muslimmajority regions. With independence, however, most missionary schools were absorbed into the new national education system. This assimilation, together with a rapid expansion of public schools to provide improved access to primary education, has meant that today a much smaller proportion of students attend mission schools in the traditional sense. The proportion of students attending Islamic schools is even smaller, although these schools appear to be growing rapidly. The relationship between religious schools_-both missionary schools and Islamic schools_-with the state has experienced a similar ebb and flow since independence. This is illustrated by the question of whether religious education should be taught in publicly funded schools. Today, 
however, there is a growing recognition that FISs have an important role to play in the efforts undertaken by Ghana in order to achieve the Millennium Development Goals.

This article provides an introductory review of the history of faith-inspired "formal" education in Ghana from its origins to today. ${ }^{3}$ The article consists of three sections. The first two sections review the history of mission schools, broadly divided into pre- and post-independence periods. Before independence, most of the schools were mission-based, and part of the debate was whether the schools should be publicly funded or not. Even though faith networks still manage a large number of schools, the market share of mission schools has decreased considerably since then, and there is now a well-accepted practice of supporting FISs with public funds provided that they meet certain standards and follow an appropriate curriculum. Greater debate seems to be currently focused on how religious education should be taught in publicly funded schools (public or faith-inspired), although issues of funding, comparative performance, and management autonomy continue to be important.

The next section is devoted to the history of Islamic education in Ghana, which is fairly different from that of mission schools. In the colonial period, Islamic education was not a priority, and somewhat off the radar screen of colonial administrators in part because of the relative isolation of the northern and majority Muslim territories, which were not perceived as of great economic value. Boyle et al. (2007) identify four different types of Islamic schools: traditional Qur’anic schools, Arabic schools, Arabic English schools, and Islamic schools under the management of the government's Islamic Education Unit (IEU). While the first three types of schools do not benefit from public funding, the last does, and thus such schools are integrated better in the government education system. There is a perception that while Islamic schools were somewhat marginal in the colonial period and in the early stages of the independence era, they 
have now benefitted for some time from a revival, related in part to a stronger affirmation by the Muslim community of its identity, and not only in the north.

While this article aims to provide a broad introductory review of the history of FISs in Ghana, it is also worth mentioning some aspects of that history that are covered extensively in the literature but not discussed here. One issue is the role of missionary education as culpable in the colonial oppression and suppression of African culture and identity—and the flipside, that missionary schools played a key role in the education of important Ghanaian nationalists (see Amanor 2004; Thompson 2002). A second issue is the intersection of missionary education and language—-with some missionary educators pioneering and promoting education in vernacular languages, and others caught up in the promotion of English as the national lingua franca (see Amanor 2004; Wyllie 1976). While this has lost some of its fervor in contemporary debates about education policy in Ghana, it remains a concern.

A third issue is whether the development of different historical patterns of faith-inspired education in different parts of the country has contributed to a stronger religious demarcation between ethnic groups, with implications for social cohesion in the country as a whole (see Thomas 1974; Weiss 2005). A fourth area not covered here is the historical role of religious groups in supporting education in ways that go beyond the provision of schools. There are accounts that religious congregations and community organizations have traditionally supported orphans and vulnerable children by supplying uniforms or books, supporting those in need of special education, and supplying scholarships for secondary and tertiary education (see Boakye and Wilson 2003; Boyle et al. 2007). This type of support usually gets recognized as "social work" or "social support," rather than as educational service provision per se. Again, this consideration falls beyond the scope of this article—but remains an area for future consideration. 


\section{Pre-independence Christian Mission Education}

Formal education in Ghana_or the Gold Coast Colony as it was earlier named—can be traced back to the $16^{\text {th }}$ century with early accounts describing the establishment of castle schools which mainly catered to children of European merchants as well as wealthy Africans. While not the typical mission school—-these castle schools usually included a curriculum of literacy (reading and writing), arithmetic, and Bible study, and they were often taught by missionaries. For example historical accounts describe the settlement of Elmina-which was noted as having been "successfully converted” to Catholicism in 1529. In 1572, four Augustinian missionaries arrived, but after four years of attempting to set up mission schools, they were killed. In 1637, a Portuguese vicar ran a school at Elmina Castle_-which ended when the Protestant Dutch seized the castle in 1637 and opened their own school in 1644 . In the $18^{\text {th }}$ century the Directors of the Danish Guinea Company invited The United Brethren mission from Germany to the Gold Coast, to teach in the castle schools (Amanor 2004; Martin 1974).

It took a further three hundred years for a broader system of missionary schools to develop and provide education to a larger number of Ghanaians. As shown in Table 1, although there were waves of different missionary groups, many of the schools established in the $19^{\text {th }}$ century originated from two groups: the Swiss-based Basel (ecumenical) Mission, mainly based in the eastern region of the colony, and the Methodist Wesleyan missionaries, mainly based in the coastal belt, west of Accra (Thompson 2002; Wyllie 1976; Berman 1974). The Basel Missionary Society opened its first school in 1843, and less than 40 years later the Society had established 45 schools ranging from kindergarten to a teacher education program. The Society also created a trading company whose profits were used to support its schools and other 
missionary activities (Gannon 1983). The growth of Wesleyan Methodist schools was even faster—84 schools had been created by 1850 (Thompson 2002). In the $19^{\text {th }}$ century, missionary groups were seen as the primary providers of national education. McWilliam and Kwamena-Poh (1975) noted that missionary providers had significantly greater resources at their disposal for education provision than the colonial government. For example it was recorded that in 1844 during a single visit to Britain, Thomas Birch Freeman collected 5,500 pounds for the work of the Wesleyan Mission in the Gold Coast, more than the Gold Coast government's total revenue for that year.

Missionary education was pluralistic and different groups experienced periods of growth and decline at different times. A significant event was the expulsion of the Bremen and Basel Missionaries from the Gold Coast in 1917, linked to British suspicion of the German (and Swiss) missionaries during the First World War. The Bremen and Basel missionaries handed over the bulk of their schools to Scottish missionaries-later to become the Presbyterian Church of Ghana (Gannon 1983; Jenkins 1978). Another interesting pattern in Ghana is that in comparison with the Protestant churches which started establishing schools in the 1840s and 1870s, the Catholic church started somewhat later with most schools being established in the $20^{\text {th }}$ century. Yet today, according to Osei-Bonsu (2010), out of the 12 Educational Units in the country, the Catholic Church Educational Unit has the greatest number of schools.

In the decades leading up to independence, mission schools became caught up in national debates and controversies. Some commentators pointed to the complicity of European-led religious mission and education with colonial oppression (whether structural, intellectual, or spiritual) and its potential focus on proselytization rather than education. Others spoke of the role of mission schools in the education of African leaders and the promotion of African nationalism 
which led to the challenge of colonial rule (see Dei 2002; Berman 1974; Wyllie 1976). While

space does not permit a discussion of these issues here, it must be noted that by the early $20^{\text {th }}$

century, although mission schools were by far the main providers of formal education, this was

no longer a comfortably accepted situation, with Africans increasingly challenging the foreign

“ownership” of religion generally, and of education in particular. The provision of education

became a bone of contention with the colonial government for the urban intelligentsia, which

began to set up its own secondary schools. Coe (2002) mentions the watershed establishment of

the Prince of Wales College in 1924-1927, later renamed Achimota, a non-denominational

secondary school and teachers' training college which was the government's first significant

indication of an interest in taking charge of the Gold Coast education system. Table 1

summarizes some of the key events relating to Christian faith-inspired or "mission” education

from the 1500s to 1957 when the Gold Coast became the independent state of Ghana.

Table 1: Selected Pre-independence Events in the History of Missionary School in Ghana

\begin{tabular}{ll}
\hline Date & Events \\
\hline $\begin{array}{l}\text { 1500s- } \\
\text { 1700s }\end{array}$ & $\begin{array}{l}\text { Era of 'castle schools' connected to missionary endeavor. In 1529 the Elmina settlement converts to } \\
\text { Catholicism; in 1572 Augustinian missionaries attempt to set up mission schools but are killed; in } \\
\text { 1637, Elmina Castle seized by Protestant Dutch who open their own school (in 1644). Other examples } \\
\text { of castle schools at the British school at Cape Coast Castle; Danish school at Christiansborg Castle. }\end{array}$ \\
\hline $1828-$ & $\begin{array}{l}\text { Swiss Basel Mission Society established with mission statement including the provision of quality } \\
\text { education and character training; First school opened in 1842; Establishment of Trading Company to } \\
\text { secure material support for educational/missionary activities in 1856. }\end{array}$ \\
\hline $1836-$ & $\begin{array}{l}\text { Methodist Wesley Girls School established at Cape Coast in 1836; 31 Methodist schools by 1856 with } \\
\text { total of 1229 pupils; Methodist Mfantsipim College established in 1876 }\end{array}$ \\
\hline 1852 & $\begin{array}{l}\text { Education Ordinance aims to centralize education on forts and settlements on the Gold Coast, but does } \\
\text { not provide grants to missions and therefore receives very little support. }\end{array}$ \\
\hline $1873-74$ & Ashanti Wars put a stop to further educational developments by the government \\
\hline $1880 s$ & $\begin{array}{l}\text { In 1881 there are 139 schools, three of which are under direct government management. The rest } \\
\text { includes 47 schools run by Basel Mission Society; 84 by Wesleyans; 4 by Bremen Mission; and one }\end{array}$ \\
& $\begin{array}{l}\text { Roman Catholic school. In 1882 the Government calls for General Board of Education to ascertain } \\
\text { conditions upon which grants are awarded and teachers certified; Education Ordinance of 1887 } \\
\text { establishes Board of Education and funds schools, including mission- schools upon certain conditions. }\end{array}$ \\
\hline &
\end{tabular}




\begin{tabular}{|c|c|}
\hline 1890 & Office of Director of Education created. Enrollment at 5,076 including 1,037 girls. \\
\hline 1901 & Wright's estimate suggests that a total of 132 mission schools are in existence \\
\hline $1900 \mathrm{~s}$ & $\begin{array}{l}\text { Ashanti and Northern Territories annexed to colony; favorable economic conditions thanks to cocoa } \\
\text { revenues finance improvements in educational sector. Push to establish schools in administrative } \\
\text { centers to train new generation of chiefs; Navrongo mission school established in Northern territory }\end{array}$ \\
\hline 1917 & Bremen and Basel missionaries expelled with advent of WW1, schools handed to Scottish Mission \\
\hline 1920 & Phelps-Stokes Educational Commission surveys education system \\
\hline 1922 & $\begin{array}{l}\text { Governor Guggisberg sets up educational committee which recommends that vernacular English be } \\
\text { used in primary education and that a government secondary school be set up }\end{array}$ \\
\hline $\begin{array}{l}\text { 1920s- } \\
1940 s\end{array}$ & $\begin{array}{l}\text { Establishment of new schools: for example, non-denominational Prince of Wales College (renamed } \\
\text { Achimota) secondary school in 1927; St. Augustine College (Anglican) in 1935; Presbyterian Boys } \\
\text { School (Odumasi-Krobo, now in Legon) in 1938; Holy Child (Roman Catholic) in } 1945 .\end{array}$ \\
\hline $1950 \mathrm{~s}$ & $\begin{array}{l}\text { Missionary schools account for } 97 \% \text { of school enrollment in } 1950 \text { (according to Berman 1974); } \\
\text { Nkrumah government with attention to mass education; Seven Year Plan includes gradual phasing out } \\
\text { of public assistance to new primary schools opened by denominational religious bodies }\end{array}$ \\
\hline 1957 & British colony of the Gold Coast becomes the independent state of Ghana \\
\hline \multicolumn{2}{|c|}{ Source: Compiled by the authors from multiple sources including Akyeampong (2010), Berman } \\
\hline & \\
\hline
\end{tabular}

\section{Post-independence Christian Mission Education}

Substantial changes took place in the post-independence period. In a 1957 address to the old Legislative Assembly, President Nkrumah outlined his government's vision, with education as one of its cornerstones. Education was to achieve three goals: producing a literate population, tackling low productivity, and developing knowledge to boost Ghana's growth. The focus was not only on primary education, but also on higher levels of education for economic development (Akyeampong 2010). Earlier, President Nkrumah had stated that no new primary school opened by a denominational religious body or by a person or group of persons will be eligible for assistance from public funds unless prior approval of the local authority concerned under powers delegated by the central government had been obtained.

In 1961, the government assumed responsibility for the payment of the salaries of 
teachers in both public and FISs (Anim 1966; Berman 1974). Most existing mission schools were essentially taken over through the 1961 Education Act, although the Act also gave significant autonomy to the schools, for example in terms of the posting of teachers or the wearing of uniforms. Because there was a perception at the time that some FISs were often admitting (or denying) pupils based on religious affiliation, Section 22 of the Act stated that no student could be refused admission on the basis of religion, race, or language. However, the Act did recognize that Religious Knowledge (RK) should be taught in all schools (see below for more on this).

The 1960s were a period of rapid expansion of public education provision, although probably at some cost to the quality of the education that was provided (Akyeampong 2010). Several reforms were implemented, including the restructuring of basic education along 10 years of elementary school with a transition in the eighth year for selecting those eligible for secondary education. Further growth in enrollment and changes were implemented in the early 1970s and the 1980s, including an emphasis of the curriculum on the development of skills to better respond to social and economic development needs (Dei 2002). In the 1980s—partly at the demand of international development organizations-a progressively stronger focus was placed on the objective of achieving universal primary basic education for all, and concurrently a reduction in funding was observed for tertiary education as a share of the GDP (Effah 2003).

The fact that enrollment in public schools grew rapidly after independence-possibly at the cost of quality—was probably one of the reasons why the emergence of a new type of privately funded schools catering to the elites was observed (Dzobo in MoE 1999). Yet this led to inequities in schooling requirements to reach tertiary education. In public schools, the model required a standard of 17 years of pre-university education (six years at the primary level, 
followed by four years of middle school and another seven years of secondary education). By contrast private school students could reach university with only 13 years of pre-tertiary education. More generally, competition took root in education, but private schools were not affordable to children from disadvantaged households (Addae-Mensah et al. 1973). It has therefore been argued that the growth of private sector provision contributed to the stratification of Ghanaian society (Addae-Mensah 2000). It is only in the late 1980s under the administration of President Rawlings that a number of reforms (initially proposed by the Dzobo Committee in 1973) were implemented, including a new educational structure with six years of primary education, three years of junior secondary education (JSS) and three years of Senior Secondary School (SSS), as well as an alternative track after JSS towards Technical and Vocational Education and Training (TVET).

After independence, the market share of mission schools was steadily reduced, not only because of the take-over of mission schools through the education Act of 1961, but also because of efforts by successive governments to expand access to education through new public schools. Mainline churches had historically been of considerable significance in building the modern Ghanaian nation-state through their schools, as they had been elsewhere in Africa (Gifford 2004). But with the expansion of public education, the missionary domination of education in Africa was significantly reduced on the continent generally, and in Ghana in particular. While missionary schools accounted for 97 percent of all schools in Ghana in 1950 (Berman 1974), half a century later, after nationalism and education reform, they enrolled less than 10 percent of the student population according to a nationally representative household survey for 2005/06.

The integration of the mission schools into the national education system also brought to the fore the question of religious education in schools. As shown in Table 2, a large part of the 
new national debate focused on this, with religious groups taking on a significant advocacy role. Awuah-Nyamekye (2010) and Asare-Danso (2008) provide a historical account of how religious education was taught in Ghanaian schools from the early colonial times through today. The 16 principles of education postulated in 1925 by Governor Guggisberg endorsed the teaching of Religious Education (McWilliam and Kwamena-Poh 1975) and promoted cooperation between the government and the missions which were to benefit from public subsidies. By contrast, while President Nkrumah endorsed religious instruction in his Accelerated Development Plan for Education, the dominance of mission schools decreased after independence, and so did religious educational content in the curriculum. In 1972 the Dzobo Review Committee maintained that religious education (then called Religious Knowledge) should be taught, but only as part of broader Cultural Studies that included not only religion, but also music and dance.

The fate of religious education became uncertain in the late 1980s. In 1987 the Provisional National Defense Council eliminated cultural studies and religious education from the core curriculum, but religious education was re-introduced in the curriculum as part of Religious and Moral Education (RME) by the National Education Reform Review Committee. In 2007, the government again removed RME from the curriculum, but re-instated it as nonexaminable subject after protests from the Christian Council of Ghana and the Catholic Church. A study on religious education in Ghana by Asare-Danso (2008) looks at this movement in more detail over the period 1957-2007. Today, it is fair to say that the government supports FISs and the teaching of religious education in all Ghanaian schools, provided that it is done professionally without aiming to convert students to any particular faith. To ensure that this is the case, the contents of such courses are approved by the Ghana Education Service. 
Table 2: Selected Post-independence Events in the History of Missionary School in Ghana

\begin{tabular}{|c|c|}
\hline Date & Events \\
\hline 1961 & Education Act: no student could be refused admission on the basis of religion, race, or language. \\
\hline 1962 & Government assumes responsibility for payment of teacher salaries in all schools. \\
\hline 1966 & Nkrumah government overthrown; rapid expansion of education provision but at risk of quality. \\
\hline 1967 & $\begin{array}{l}\text { Kwapong Committee proposes educational structured based on ten years of elementary education with } \\
\text { a break in year eight for selecting suitable candidates for secondary education. }\end{array}$ \\
\hline 1973 & $\begin{array}{l}\text { Dzobo Committee proposes new educational structure with six years of primary education, three years } \\
\text { for junior secondary education (JSS), and three years for Senior Secondary School (SSS), and more } \\
\text { emphasis on vocational and technical subjects. It recommends that Religious Knowledge (RK) be part } \\
\text { of Cultural Studies with music and dance. }\end{array}$ \\
\hline 1974 & GES established by National Redemption Council Decree as part of the Public Service. \\
\hline 1987 & $\begin{array}{l}\text { Provisional National Defense Council abolishes middle schools and adopts three years of JSS and four } \\
\text { years of SSS (Dzobo Committee recommendation). Primary and JSS become basic education. Cultural } \\
\text { Studies and religious education ceased to be part of the basic curriculum. }\end{array}$ \\
\hline 1994 & $\begin{array}{l}\text { National Education Reform Review Committee set up with review function. Religious Education is re- } \\
\text { introduced as part of curriculum on Religious and Moral Education (RME). }\end{array}$ \\
\hline 1995 & $\begin{array}{l}\text { Free, Compulsory, Universal Basic Education (FCUBE) includes capitation grants and district-level } \\
\text { responsibilities. New syllabus in } 1998 \text { for teaching of RME at basic/SSS levels. }\end{array}$ \\
\hline 2004 & $\begin{array}{l}\text { New Education Act yields regulations for the management of schools in partnership with religious } \\
\text { bodies as of 2005. Commitment to collaborate with religious bodies in non-partisan way, review } \\
\text { partnership arrangements, and develop regulations for FISs. }\end{array}$ \\
\hline 2007 & $\begin{array}{l}\text { Senior Secondary School expanded to four years and Technical and Vocational Education and } \\
\text { Training (TVET) strengthened. Restructuration of pre-tertiary education to prepare all students for } \\
\text { tertiary institutions or the job market (apprenticeships). }\end{array}$ \\
\hline
\end{tabular}

2007 Anamoah-Mensah reform - contrary to the committee's recommendations, the government removes RME from the curriculum, but re-instates RME as non-examinable subject after protests from the Christian Council of Ghana and the Catholic Secretariat.

Source: Compiled by the authors (see references for more bibliographical sources: Akyeampong

2010; Anim 1966; Awuah-Nyamekye 2010; Berman 1974 and Asare-Danso 2008.

\section{Islamic Education}

Boyle et al. (2007) conducted a substantial review of the literature on Islamic education

in Ghana, and this section draws mainly from their work. Formal Islamic education first came to

Africa through Abyssinia, spreading to North Africa. Islam spread through the Ancient Kingdom

of Ghana (and thereafter into sub-Saharan Africa) after the Umayyad invasion of North Africa in 
705. Muslim communities were highly mobile and they brought their education system with them. Wherever they settled, communities established their own small Qur'anic schools with parents usually paying the teacher and maintaining the school, usually free of administrative structures (Boyle et al. 2007).

During the colonial period, however, Islamic schools did not develop as fast as the Christian mission schools_-in part because they were not connected to the colonial administration as the Christian missions were. Although there are few historical accounts of Islamic schools in Ghana in that period, the schools were certainly present at the time. Trimingham (1962) notes the role of itinerant Islamic scholars from the Hausa community who came as traders and artisans in the 1700s and brought Arabic literacy to the region (the Dagbomba Kingdom). The arrival of Western powers and missionary educators most likely had a negative impact on the preeminence of Islamic education. Boyle et al. (2007) note that during the colonial period, great energy was given to thinking about how the Muslims (then mainly in the northern region) could be dealt with, and suggestions to introduce Muslims to Western secular (and Christian) education were common. However, despite this, there are records of continued activity of significant Islamic scholars in the Gold Coast in the 1800s, such as Mallam Ghamba who led a school in Kumasi in 1807, and Al Haj Umar who migrated to Salaga from Hausaland in 1974.

Iddrisu (2002) notes that Islamic education most significantly penetrated the Gold Coast region after the $19^{\text {th }}$ century Jihad Movements in Northern Nigeria, primarily in connection to Islamic proselytization. However, he also indicates that the information sources fail to indicate the precise number of Islamic (or Qur'anic) schools in existence. While Saidu (1989) suggests that in 1935 there were about 50 Qur'anic schools in the whole area, Iddrisu contends that the 
actual number far exceeds this figure (estimation is difficult due to the tradition of naming new Qur'anic schools with the same name as the tradition from which they emerged).

During the colonial period, Education was addressed quite differently in the northern regions to the rest of the Gold Coast region (Thomas 1974; Iddrisu 2002, 2005). In a nutshell, in the early stages of colonization, there was limited access to the northern territory, where the majority of the Muslim population resided. Thomas (1974) points out that the colonial administration generally gave little priority to this area, since it offered fewer exportable crops or minerals, and also because of significant access and transport difficulties. The northern protectorate was administrated as a separate entity—and as a result had a distinct social development. The administration also limited Christian missionary activity in this area. For example, the (Catholic) White Fathers' mission was allowed to operate in this area, and then the Wesleyans, but care was taken to ensure that this did not interfere too strongly with local customs and institutions. Thomas (1974) argues that this was done to maintain the power of traditional institutions. Iddrisu (2005) notes that the conflicting reasons have been given for this restraint—-some argue that it was motivated to reduce the risk of conflict between the religions while others suggest that the intent was to slow progress in the north as part of a colonial administrative strategy. Whatever the reason, a series of failed education attempts on the part of the colonial administration in the north meant that the population was slow to adopt secular education—a sentiment that continues today (Iddrisu 2005).

As a result, in the first half of the $20^{\text {th }}$ century before independence, Muslims in the north continued to rely on their own education tradition without much support from the colonial administration. For example, while Governor Guggisberg is associated with significantly expanding the focus on education in the colony in general, he also declared his distaste for the 
spread of Islam and indicated in 1925 the desire of the colonial administration to help the Christian missions against the advance of Islam (Iddrisu 2005). However, in the north, Guggisberg’s educational policy still avoided interfering with traditional forms of Muslim authority (Thomas 1974).

Iddrisu (2005) identifies three main challenges to Islamic learning and Muslim education in the Gold Coast under the colonial era-with subsequent impact on post-independence education. Firstly, there was an effective exclusion of the Christian missionary effort in the north, although missionary efforts continued to challenge Islamic learning (and the Muslim culture) in other regions of the Gold Coast. Secondly, the half-hearted introduction of secular education in the northern protectorate, with the instruction that progress be halted at standard three and with a focus on educating only sons of chiefs, led to limited access. Thirdly, the focus on maintaining the status quo through the traditional powers in the Muslim-dominated area, in order to create an enabling environment for economic exploitation also hindered Islamic education. The north became essentially a reservoir of cheap labor for plantations and mines in the south, so that improving education in those areas was not seen as a priority.

Weiss (2005) notes that these strategies during the colonial period led to divisions between Muslim and non-Muslims in Ghana, generating a slow process of religious demarcation of ethnic groups. While Muslim communities saw mission schools as a threat and thereby chose to provide only a (religious) Muslim education to their children, Western-style education was seen as an opportunity in the south. This contributed to the marginalization of Muslims and to substantial differences in education attainment between the north and the rest of the country. After independence, many Muslims continued to be skeptical of the Christian-influenced, Western secular system of education. As noted by Boyle et al. (2007), it took some time for 
Muslim communities to realize that they had to promote secular subjects in their schools if they were not to be left out of rewarding jobs in government and elsewhere. This realization has now led to the emergence of new Islamic schools that integrate secular and religious education.

Boyle et al. (2007) identify four major categories of Islamic schools today in Ghana (while recognizing that these categories are fluid): the private Traditional Qur'anic schools, the Arabic schools, the Arabic English schools, and the public Islamic schools. Traditional Qur'anic schools (also called makaranta) focus almost exclusively on Qur'anic memorization. They are still widespread, but today they operate mostly outside of normal school hours as an additional educational experience. Arabic schools provide some secular subjects, but with Arabic as the main language of instruction, and a focus on religious subjects. Arabic English schools are private schools that generally offer the government curriculum and a program of religious and Arabic language studies. These schools are often financed through user fees, the benevolence of school proprietors, Muslim non-governmental organizations, ${ }^{4}$ and donations from abroad. The fourth type of Islamic school falls under the management of the Islamic Education Unity (IEU), a unit established in 1987 to oversee the transformation and integration of Islamic schools into the public schools. These schools are formally public schools benefiting from government subsidies for teachers and textbooks. They follow the official curriculum, but also offer Arabic and Islamic studies.

Overall, as noted by Iddrisu (2002, 2005), integration of these different forms of Education has been on the rise, but there are still some concerns including lingering distrust, a lack of controls for establishing Islamic schools, a lack of suitably-trained Islamic and Arabic teachers who can teach an integrated curriculum, a lack of Islamic secondary schools to absorb students from the growing number of Islamic primary schools, and challenges related to differing 
skill levels in various subjects across schools that make it difficult for students to shift from one

schooling system to another. Table 3 summarizes some of events related to the history of Islamic

School in Ghana discussed above.

\section{Table 3: Selected Events Specific to the History of Islamic School in Ghana}

\begin{tabular}{|c|c|}
\hline Date & Events \\
\hline $1780-90$ & Description of Salaga as a town where everyone could read and write in Arabic. \\
\hline 1807 & Islamic scholar, Mallam Ghamba recorded as having a school in Kumasi. \\
\hline 1874 & Islamic scholar Al Haj Umar migrates to Salaga from Hausaland, teaching Arabic and Islam. \\
\hline 1877 & $\begin{array}{l}\text { David Asante, an early African clergyman of the Basel Mission, reports the existence of many Islamic } \\
\text { schools, where children recite Arabic, learn to read and write, and pay school fees. }\end{array}$ \\
\hline 1921 & Ahmadiyya missionary initiative establish their headquarters and a school at Saltpond. \\
\hline 1932 & $\begin{array}{l}\text { First attempt to integrate secular subjects into Islamic system as the Ahmadiyya Mission aims to } \\
\text { generate more interest in government schools among Muslims. }\end{array}$ \\
\hline 1935 & There are at least about 50 Qur'anic schools in the northern region (the figure may be much higher). \\
\hline 1940 & $\begin{array}{l}\text { Ahmadiyya Primary School established at Zogbeli in Tamale - success at integration in the national } \\
\text { education system. The school later shed its religious character and adopted a secular curriculum. }\end{array}$ \\
\hline 1951 & Accelerated Development Plan for Education has significant impact on Northern region education. \\
\hline $1960 \mathrm{~s}$ & Leading Mallams employed to instruct Muslim students at some mainstream secular schools. \\
\hline 1973 & $\begin{array}{l}\text { Ghana Educational Service and proprietors of the Islamic schools reach agreement - while the schools } \\
\text { remain private and the property of individual proprietors who must provide classrooms and furniture, } \\
\text { GES provides and pays secular teachers; Arabic/ Islamic instructors are provided by the proprietors. }\end{array}$ \\
\hline $1972-73$ & $\begin{array}{l}\text { Government provides teachers to some Islamic schools, integrating secular subjects into the Islamic } \\
\text { schools' curriculum - introducing these schools into the public education system. }\end{array}$ \\
\hline 1973-1976 & $\begin{array}{l}\text { Abruquah (Northern Regional Director of Education) encourages Islamic schools to enable them to } \\
\text { “...do for the north what Christianity had done for Southern Ghana, educationally” (in Iddrisu 2005). }\end{array}$ \\
\hline 1974 & $\begin{array}{l}\text { Establishment of Islamic Education Unit (IEU) schools - Makarantas that are persuaded to accept } \\
\text { secular subjects and teachers. The first four were the Anbariyya Islamic Institute, the Nurul Islam } \\
\text { Islamic School, the Nah'da Islamic School, and the Nurriya Islamic Institute. }\end{array}$ \\
\hline 1976 & There are about 200 recognized Islamic schools in the Northern Region. \\
\hline 1980 & The Nuriyya Islamic Unit inaugurates its headquarters in Tamale. \\
\hline 1987 & $\begin{array}{l}\text { The IEU oversees and assists in the transformation of traditional schools into public schools that teach } \\
\text { the government curriculum but maintain their religious character and also teach religious subjects. }\end{array}$ \\
\hline 2002 & Islamic University College established in Accra \\
\hline
\end{tabular}




\section{Conclusion}

The objective of this article was to provide an introductory review of the history of faithinspired education in Ghana in order to provide context to some of the other articles in this special issue that focus mostly on contemporary assessments of FISs. Faith-inspired education has a long tradition in Ghana, and this is the case for both Islamic and Christian mission-based schools. In the colonial period, and especially as of the 1800s, Christian mission-based schools enjoyed a leadership position. Up to independence, most of the children enrolled in schools attended missionary schools. This changed after independence with the incorporation of most mission schools in the public education system and the rapid growth over the last 50 years of new public schools in order to provide access to universal primary education. Today, mission schools represent only a small (although still significant) fraction of all schools in Ghana. As for Islamic schools, they pre-date Christian mission-based schools by several centuries, but they maintained a smaller footprint in the colonial and post-independence era. Today, the proportion of students attending Islamic schools is lower than is the case for mission-based schools, but there is evidence that this sector may be growing.

The relationship between religious schools—both missionary and Islamic_-with the state went through ups and downs over the last 30 years, with constant dialogue occurring as attempts were made to streamline and align what was historically a diverse educational patchwork into a coherent national system. Generally speaking, the government of Ghana now recognizes the important role of FISs, and both Christian and Islamic bodies appear to have a significant advocacy voice as education policies are adjusted and developed.

Even if their history is very different, a number of issues are currently held in common between Christian mission-based and Islamic schools, including the requirements that must be 
met in order to benefit from public funding and the space that can be granted in the curriculum to religious education. In terms of quality, clearly some of the Christian mission and Islamic schools were and still are perceived to be of high quality, but there are also concerns that some of the new schools (both Islamic and Christian, including Pentecostal schools) that are emerging may not all be of the same quality. These schools are sometimes being created because of a lack of alternatives, or because they respond to the desire of parents for faith-inspired education. Private secular schools are also growing, albeit more in urban and peri-urban areas.

These new trends, while not discussed here, may be generating a divergence in terms of who is served by which types of school. Quasi for-profit private schools may be serving urban centers, while new unrecognized schools, some of which are faith-inspired, may be managed by faith groups and charitable organizations in rural areas or in low income neighborhoods at the periphery of cities. While new FISs may be filling gaps or niches in the demand for education that places a high emphasis on faith and values, it will be important to make sure that the education provided by these new FISs meet the quality standards that have traditionally been associated with Christian and Islamic FISs in Ghana.

\section{References}

Addae-Mensah, Ivan, Jerome Djangmah and C. Agbenyega. 1973. Family Background and Educational opportunity in Ghana. Accra: Ghana Universities Press.

Addae-Mensah, Ivan. 2000. "Education in Ghana: A Tool for Social Mobility or Social 
Stratification.” The J.B. Danquah Memorial Lectures, April 2000.

Adoho, Franc, Clarence Tsimpo and Quentin Wodon. 2014. "Public, Private, and Faith-inspired Schools in Ghana: A Comparative Assessment,” The Review of Faith \& International Affairs, this issue.

Akyeampong, Kwame. 2009. "Public-private Partnership in the Provision of Basic Education in Ghana: Challenges and Choices,” Compare: A Journal of Comparative and International Education, 392: 135-149.

Akyeampong, Kwame. 2010. “50 Years of Educational Progress and Challenge in Ghana”In CREATE Pathways to Access, Research Monograph No. 33. Falmer, UK: Centre for International Education, University of Sussex, UK.

Akyeampong, Kwame, Jerome Djangmah, Abena Oduro, Alhassan Seidu, and Frances Hunt. 2007. “Access to Basic Education in Ghana: The Evidence and the Issues, Country Analytic Report.” Centre for International Education (CREATE), Sussex School of Education, University of Sussex, Brighton, UK.

Amanor, Jones Darkwa. 2004. "Pentecostalism in Ghana: An African Reformation.” CyberJournal for Pentecostal-Charismatic Research 13:1-34.

Asare-Danso, Seth. 2008. "Religious Education in a Democratic State: The Ghanaian 
Experience.” Unpublished Report, Cape Coast, Ghana: Department of Arts \& Social Sciences Education, Faculty of Education University of Cape Coast.

Anim, Nicholas. 1966. “Ghana.” In Church, State, and Education in Africa, edited by D.G. Scanlon, 165-196. New York: Teachers College Press.

Awuah-Nyamekye, Samuel. 2010. "Religious Education in a Democratic State: The Case of Ghana." Conference proceedings of International Conference on Religious Education in a Democratic State held on June 6-8, 2010, at Bar- Ilan University TelAviv, Israel.

Berman, Edward H. 1974. “African Responses to Christian Mission Education.” African Studies Review 17(3): 527-540.

Boakye J. K. A., Agyeman-Duah, J., Osei, J., and M. Brew-Ward. 1997. Causes of Dropout from Basic Education in Ghana. Accra: Ministry of Education.

Boyle, Helen N., Sheikh Zakaria Seebaway, Ismail Lansah, and Abdenour Boukamhi. 2007. “Islamic Education Sector Study: Ghana.” Accra, Education Development Center, Northern Ghana Network for Development for USAID.

Coe, Cati. 2002. "Educating an African Leadership: Achimota and the Teaching of African Culture in the Gold Coast.” Africa Today 49(3): 23-44. 
Dei, George J. Sefa. 2002. "Spirituality in African Education: Issues, Contentions and Contestations from a Ghanaian Case Study,” International Journal of Children's Spirituality 7(1): 37-56.

Effah, Paul. 2003. “A Decade of Polytechnic Education in Ghana: An Assessment of Achievements and Failures.” In African Higher Education: An International Reference Handbook, edited by D. Teferra and P. Altbach. Indianapolis: Indiana University Press.

Etsey, Kafui, Thomas M. Smith, Emma Gyamera, Joe Koka, Jennifer de Boer, Emmanuel Havi and Stephen P. Heyneman. 2009. "Review of Basic Education Quality in Ghana: Basic Education in Ghana: Progress and Problems.” The Mitchell Group for the United States Agency for International Development (USAID).

Gannon, Margaret. 1983. “The Basle Mission Trading Company and British Colonial Policy in the Gold Coast, 1918-1928.” The Journal of African History 24(4): 503-515.

Gifford, Paul. 2004. Ghana’s New Christianity. Indianapolis: Indiana University Press.

Iddrisu, Abdulai. 2002. "Between Islamic and Western Secular Education in Ghana: A Progressive Integration Approach.” Journal of Muslim Minority Affairs 22(2): 335-350.

Iddrisu, Abdulai. 2005. “The Growth of Islamic Learning in Northern Ghana and its Interaction with Western Secular Education.” Africa Development 30(1\&2): 53-67. 
Jenkins, Paul O. 1978. “The Ghana Archive of the Basel Mission, 1829-1917 Contents of the microfilm collection.” West Yorkshire: Microform Academic Publishers.

Martin, Charles A. 1976. "Significant Trends in the Development of Ghanaian Education.” The Journal of Negro Education 45(1): 46-60.

Mettle-Nunoo, Rojo, and Louise. Hilditch. 2000. “Donor Participation in the Education Sector in Ghana.” ActionAid, Brussels.

McWilliam, Henry Ormiston Arthur, and Michael A. Kwamena-Poh. 1975. The Development of Education in Ghana. London: Longman.

Osei-Bonsu, Joseph. 2010. "Provision of Quality Education in Ghana: The Role of the Catholic Church.” First Graduation Ceremony of the Spiritan University College, 19 June, Ejisu, Ghana.

Saidu, Saifu Abdel. 1989. "The Influences of Islam on Dagomba in the Twentieth Century.” MPhil thesis, University of Ghana, Legon.

Thomas, Roger G. 1974. “Education in Northern Ghana, 1906-1940: A Study in Colonial Paradox.” The International Journal of African Historical Studies 7(3): 427-467. 
Trimingham, J. Spencer. 1962. A History of Islam in West Africa. London: Oxford University

Press.

Weiss, Holger. 2005. "Contested Historical and Geographical Narratives: Succession Disputes, Contested Land Ownership, and Religious Conflicts in Northern Ghana.” In Working Papers on Ghana: Historical and Contemporary Studies, Vol. 6: 1-18.

Wyllie, Robert W. 1976. "Some Contradictions in Missionizing.” Africa: Journal of the International African Institute 46: 196-204.

\footnotetext{
${ }^{1}$ The authors are with the University of Cape Town and The World Bank. The opinions expressed in this article are those of the authors only and need not represent those of the World Bank, its Executive Directors or the countries they represent.

${ }^{2}$ Berman (1974) estimates that by 1950, missionary schools accounted for 97 percent of total enrolment in Ghana.

${ }^{3}$ We do not discuss here other kinds of 'informal' education systems predating colonization, such as traditional African educational practices.

${ }^{4}$ For example, the Ghana Education Trust Fund (GETFund) established a project to build schools and supply various textbooks necessary to improve the education of the girl-child. The local chapter of the Federation of African Women Educationist (FAWE) has also been very active in this awareness creation in the form of the TV clip Send your Girl-child to School by the Ghana Chapter of FAWE. And the Ghana National Association of Teachers (GNAT), in collaboration with the Swedish Teachers Federation, is supplying furniture to schools all over the country to increase enrolment of the girl-child in schools in Muslim communities (Boyle et al. 2007).
} 